\title{
Ethane Oxidative Dehydrogenation Pathways on Vanadium Oxide Catalysts
}

\author{
Morris D. Argyle, Kaidong Chen, ${ }^{\dagger}$ Alexis T. Bell,* and Enrique Iglesia* \\ Chemical Sciences Division, E. O. Lawrence Berkeley National Laboratory, and Department of Chemical \\ Engineering, University of California, Berkeley, California 94720-1462
}

Received: December 10, 2001

\begin{abstract}
Kinetic and isotopic tracer and exchange measurements were used to determine the identity and reversibility of elementary steps involved in ethane oxidative dehydrogenation $(\mathrm{ODH})$ on $\mathrm{VO}_{x} / \mathrm{Al}_{2} \mathrm{O}_{3}$ and $\mathrm{VO}_{x} / \mathrm{ZrO}_{2}$. $\mathrm{C}_{2} \mathrm{H}_{6}-$ $\mathrm{C}_{2} \mathrm{D}_{6}-\mathrm{O}_{2}$ and $\mathrm{C}_{2} \mathrm{H}_{6}-\mathrm{D}_{2} \mathrm{O}-\mathrm{O}_{2}$ react to form alkenes and $\mathrm{CO}_{x}$ without concurrent formation of $\mathrm{C}_{2} \mathrm{H}_{6-x} \mathrm{D}_{x}$ or $\mathrm{C}_{2} \mathrm{H}_{4-x} \mathrm{D}_{x}$ isotopomers, suggesting that $\mathrm{C}-\mathrm{H}$ bond cleavage in ethane and ethene is an irreversible and kinetically relevant step in $\mathrm{ODH}$ and combustion reactions. Primary ethane ODH reactions show normal kinetic isotopic effects $\left(k_{\mathrm{C}-\mathrm{H}} / k_{\mathrm{C}-\mathrm{D}}=2.4\right)$; similar values were measured for ethane and ethene combustion (1.9 and 2.8, respectively). ${ }^{16} \mathrm{O}_{2}-{ }^{18} \mathrm{O}_{2}-\mathrm{C}_{2} \mathrm{H}_{6}$ reactions on supported $\mathrm{V}^{16} \mathrm{O}_{x}$ domains led to the initial appearance of ${ }^{16} \mathrm{O}$ from the lattice in $\mathrm{H}_{2} \mathrm{O}, \mathrm{CO}$, and $\mathrm{CO}_{2}$, consistent with the involvement of lattice oxygen in $\mathrm{C}-\mathrm{H}$ bond activation steps. Isotopic contents are similar in $\mathrm{H}_{2} \mathrm{O}, \mathrm{CO}$, and $\mathrm{CO}_{2}$, suggesting that $\mathrm{ODH}$ and combustion reactions use similar lattice oxygen sites. No ${ }^{16} \mathrm{O}^{18} \mathrm{O}$ isotopomers were detected during reactions of ${ }^{16} \mathrm{O}_{2}-$ ${ }^{18} \mathrm{O}_{2}-\mathrm{C}_{2} \mathrm{H}_{6}$ mixtures, as expected if dissociative $\mathrm{O}_{2}$ chemisorption steps were irreversible. The alkyl species formed in these steps desorb irreversibly as ethene and the resulting $\mathrm{O}-\mathrm{H}$ groups recombine to form $\mathrm{H}_{2} \mathrm{O}$ and reduced $\mathrm{V}$ centers in reversible desorption steps. These reduced $\mathrm{V}$ centers reoxidize by irreversible dissociative chemisorption of $\mathrm{O}_{2}$. A pseudo-steady state analysis of these elementary steps together with these reversibility assumptions led to a rate expression that accurately describes the observed inhibition of $\mathrm{ODH}$ rates by water and the measured kinetic dependence of $\mathrm{ODH}$ rates on $\mathrm{C}_{2} \mathrm{H}_{6}$ and $\mathrm{O}_{2}$ pressures. This kinetic analysis suggests that surface oxygen, $\mathrm{OH}$ groups, and oxygen vacancies are the most abundant reactive intermediates during ethane $\mathrm{ODH}$ on active $\mathrm{VO}_{x}$ domains.
\end{abstract}

\section{Introduction}

Oxidative dehydrogenation $(\mathrm{ODH})$ provides an exothermic and thermodynamically favored route to ethene using ethane as the reactant. The formation of water overcomes the thermodynamic hurdles and the high temperatures involved in nonoxidative thermal or catalytic routes to ethene. Many previous studies have examined several metal oxides as catalysts ${ }^{1-11}$ and $\mathrm{VO}_{x}$-based materials are among the most active and selective catalysts for ethane ODH. Ethane ODH reactions occur in parallel with ethane combustion and with combustion of the ethene formed in primary ODH steps (Scheme 1). These pathways lead to the observed effects of reactor residence time on reaction rate and selectivity. ${ }^{11}$ In Scheme $1, k_{1}, k_{2}$, and $k_{3}$ represent pseudo-first-order rate constants for ethane oxidative dehydrogenation, ethane combustion, and ethene combustion, respectively. Several other reaction schemes and mechanisms have been proposed for ethane ODH on vanadia and other active oxides. ${ }^{1-9}$ Previous studies on $\mathrm{VO}_{x}-\mathrm{SiO}_{2}$ have provided the most detailed mechanistic picture for ethane reactions, ${ }^{6-9}$ but for catalysts leading to more complex reaction products, including acetone and acetaldehyde.

Previous reports have based their mechanistic conclusions on the kinetic dependence of these reactions on $\mathrm{C}_{2} \mathrm{H}_{6}$ and $\mathrm{O}_{2}$, without independent evidence from isotopic tracer or exchange studies for the role of lattice oxygen and for the reversibility or

* To whom correspondence should be addressed [E-mail: iglesia@ cchem.berkeley.edu; bell@cchem.berkeley.edu].

Current address: General Electric Corporation, 1 Research Circle, GECRD, CEB 417, Niskayuna, New York 12309.
SCHEME 1: Primary and Secondary Reaction Pathways in Oxidative Dehydrogenation of Ethane

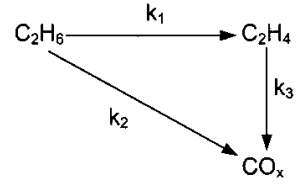

kinetic relevance of specific elementary steps. Such details have been recently reported for propane ODH reactions on supported $\mathrm{VO}_{x}, \mathrm{MoO}_{x}$, and $\mathrm{WO}_{x}{ }^{12-14}$ Both primary and secondary reactions were shown to proceed via Mars-van Krevelen ${ }^{15}$ pathways involving lattice oxygen atoms, which are removed and restored during each catalytic turnover.

Here, we report isotopic tracer and exchange studies of ethane dehydrogenation and combustion pathways $\mathrm{VO}_{x} / \mathrm{Al}_{2} \mathrm{O}_{3}$ and $\mathrm{VO}_{x} /$ $\mathrm{ZrO}_{2}$ catalysts. A sequence of elementary steps consistent with ethane ODH kinetic data was confirmed by isotopic tracer and exchange measurements and by kinetic isotope effects obtained from relative rate constants measured for each of the three rate constants in Scheme 1 using $\mathrm{C}_{2} \mathrm{H}_{6}-\mathrm{O}_{2}$ and $\mathrm{C}_{2} \mathrm{D}_{6}-\mathrm{O}_{2}$ mixtures $\left(k_{\mathrm{nH}} / k_{\mathrm{nD}}\right)$. The rate expression derived from the proposed catalytic sequence accurately describes ethane ODH rates on $\mathrm{VO}_{x} / \mathrm{Al}_{2} \mathrm{O}_{3}, \mathrm{VO}_{x} / \mathrm{ZrO}_{2}$, and unsupported $\mathrm{V}_{2} \mathrm{O}_{5}$ catalysts.

\section{Experimental Section}

$\mathrm{VO}_{x} / \mathrm{Al}_{2} \mathrm{O}_{3}$ catalysts were prepared by incipient wetness impregnation of $\gamma$-alumina (Degussa, AG, $100 \mathrm{~m}^{2} / \mathrm{g}$ ) with aqueous solutions of ammonium metavanadate containing also 
TABLE 1: Surface Area and V Surface Density for VO Catalysts

\begin{tabular}{ccc}
\hline $\begin{array}{c}\mathrm{V}_{2} \mathrm{O}_{5} \text { loading } \\
(\text { wt } \%)\end{array}$ & $\begin{array}{c}\text { surface area } \\
\left(\mathrm{m}^{2} / \mathrm{g}\right)\end{array}$ & $\begin{array}{c}\text { nominal } \mathrm{VO}_{x} \text { surface } \\
\text { density }\left(\mathrm{V} / \mathrm{nm}^{2}\right)\end{array}$ \\
\hline $2 \mathrm{~V}_{2} \mathrm{O}_{5} / \mathrm{Al}_{2} \mathrm{O}_{3}$ & 95 & 1.4 \\
$10 \mathrm{~V}_{2} \mathrm{O}_{5} / \mathrm{Al}_{2} \mathrm{O}_{3}$ & 83 & 8.0 \\
$30 \mathrm{~V}_{2} \mathrm{O}_{5} / \mathrm{Al}_{2} \mathrm{O}_{3}$ & 58 & 34.2 \\
$10 \mathrm{~V}_{2} \mathrm{O}_{5} / \mathrm{ZrO}_{2}$ & 170 & 3.9
\end{tabular}

oxalic acid. The impregnated samples were dried, crushed, treated in dry air at $773 \mathrm{~K}$, and sieved to retain $180-355 \mu \mathrm{m}$ particles. Catalyst synthesis and structural characterization procedures and the results were reported previously. ${ }^{11} \mathrm{VO}_{x} / \mathrm{ZrO}_{2}$ catalysts were prepared similarly using $\mathrm{Zr}$ oxyhydroxide powders as supports. ${ }^{16,17}$ Table 1 shows surface areas and nominal vanadia surface densities for the catalysts.

The effects of reactant and product concentrations on reaction rates and rate constants were measured using a packed-bed flow reactor with plug-flow hydrodynamics. $\mathrm{VO}_{x} / \mathrm{Al}_{2} \mathrm{O}_{3}$ and $\mathrm{VO}_{x} /$ $\mathrm{ZrO}_{2}$ catalysts $(0.01-0.3 \mathrm{~g}, 180-355 \mu \mathrm{m})$ and $\mathrm{V}_{2} \mathrm{O}_{5}$ powders (Johnson Matthey, 99.9\%, 0.49-0.78 g, <355 $\mu \mathrm{m}$ ) were diluted with quartz granules $(180-355 \mu \mathrm{m}, 0.01-0.3 \mathrm{~g})$ in order to prevent temperature gradients and to ensure plug-flow hydrodynamics. No products were detected on $\mathrm{Al}_{2} \mathrm{O}_{3}, \mathrm{ZrO}_{2}$, quartz chips, or an empty reactor at the conditions of this study. Reaction rates were measured on $\mathrm{VO}_{x} / \mathrm{ZrO}_{2}\left(3.9 \mathrm{~V} / \mathrm{nm}^{2}\right)$ at ethane pressures of $2-15 \mathrm{kPa}$ and $\mathrm{O}_{2}$ pressures of $1-4 \mathrm{kPa}$. Kinetic inhibition by products was probed by adding up to 10 $\mathrm{kPa} \mathrm{H}_{2} \mathrm{O}$ and $1 \mathrm{kPa} \mathrm{CO}_{x}\left(\mathrm{CO}_{2}\right.$ : Liquid Carbonic, 50.3\%, balance $\mathrm{N}_{2}$; CO: Praxair, 2\%, balance $\mathrm{He}$ ) to the feed. $\mathrm{H}_{2} \mathrm{O}$ was introduced by flowing $\mathrm{H}_{2}$ (Airgas, 99.99\%) over a $\mathrm{CuO}$ bed (100 g, $\left.13 \mathrm{wt} \% \mathrm{CuO} / \mathrm{Al}_{2} \mathrm{O}_{3}\right)$ at $623 \mathrm{~K}$ in order to convert all the $\mathrm{H}_{2}$ to $\mathrm{H}_{2} \mathrm{O}$. All transfer lines after $\mathrm{H}_{2} \mathrm{O}$ introduction were kept at $\sim 400 \mathrm{~K}$. Kinetic measurements were also carried out on three $\mathrm{VO}_{x} / \mathrm{Al}_{2} \mathrm{O}_{3}$ samples with surface densities of 1.4, 8.0, and $34 \mathrm{~V} / \mathrm{nm}^{2}$. In these measurements, the $\mathrm{C}_{2} \mathrm{H}_{6}$ pressure was kept at $14 \mathrm{kPa}$ and $\mathrm{O}_{2}$ partial pressures were varied (1.7-6.8 $\mathrm{kPa}$ ) in order to achieve $\mathrm{C}_{2} \mathrm{H}_{6} / \mathrm{O}_{2}$ ratios of 2-8. The $\mathrm{C}_{2} \mathrm{H}_{6}$ pressure was changed to $3.4 \mathrm{kPa}$ and then to $6.8 \mathrm{kPa}$, while keeping the $\mathrm{O}_{2}$ pressure at $1.7 \mathrm{kPa} . \mathrm{C}_{2} \mathrm{H}_{6}$ (Scott Specialty Gases, research grade, $>99.999 \%$ ) and $\mathrm{O}_{2}$ (Praxair, research grade, chemical purity $>99.999 \%$ ) were used without further purification in all experiments. Helium (Airgas, research grade $>99.9999 \%$ ) was used as an inert diluent.

Typical $\mathrm{C}_{2} \mathrm{H}_{6}$ and $\mathrm{O}_{2}$ conversions were $1-2 \%$ and $10-20 \%$, respectively. A Hewlett-Packard 6890 gas chromatograph equipped with packed (Supelco Carboxen 1004) and capillary (HP-1, $50 \mathrm{~m}, 320 \mu \mathrm{m}$ ) columns and thermal conductivity and flame ionization detectors was used to measure reactant and product concentrations in the effluent stream. The reaction temperature was varied between 663 and $743 \mathrm{~K}$ and reactor residence times were adjusted by varying ethane molar flow rates between 0.017 and $0.17 \mathrm{~mol} / \mathrm{s}$ g-atom $\mathrm{V}$. Reaction rate data as a function of residence time were used in order to calculate initial rates for primary dehydrogenation and combustion reactions and each of the rate constants in Scheme $1 .{ }^{11}$

Isotopic studies were conducted using a gradientless recirculating batch reactor with catalyst samples $(\sim 0.1 \mathrm{~g})$ held in a shallow bed at $663 \mathrm{~K} .{ }^{18}$ Gradientless operation was ensured by keeping $\mathrm{C}_{2} \mathrm{H}_{6}$ and $\mathrm{O}_{2}$ conversions below $1 \%$ per pass. Reactants were introduced into the recirculating volume $\left(400 \mathrm{~cm}^{3}\right)$ after evacuation to $<0.1 \mathrm{~Pa}$. A graphite gear pump was used to circulate reactor contents at $1.67 \mathrm{~cm}^{3} \mathrm{~s}^{-1}$. The chemical and isotopic compositions of reactants and products were measured by injecting gas samples into a gas chromatograph equipped

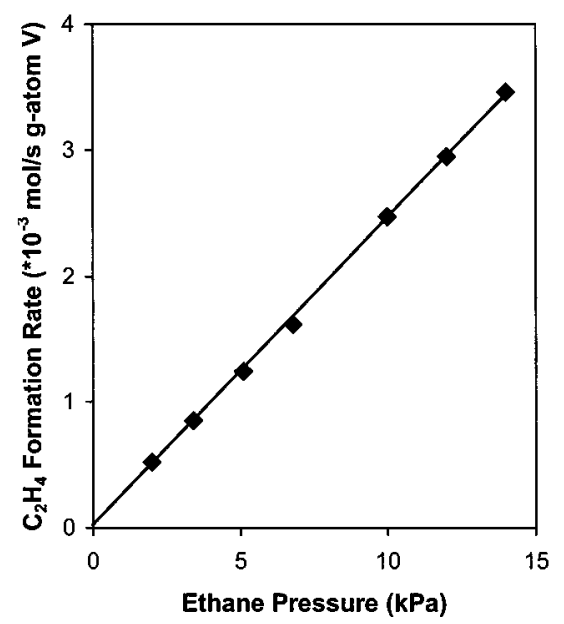

Figure 1. Effect of $\mathrm{C}_{2} \mathrm{H}_{6}$ concentration on $\mathrm{C}_{2} \mathrm{H}_{4}$ formation rate on 10 wt $\% \mathrm{~V}_{2} \mathrm{O}_{5} / \mathrm{ZrO}_{2}\left(3.9 \mathrm{~V} / \mathrm{nm}^{2}\right)\left[1.7 \mathrm{kPa} \mathrm{O}_{2}\right.$, balance $\left.\mathrm{He}, 723 \mathrm{~K}\right]$.

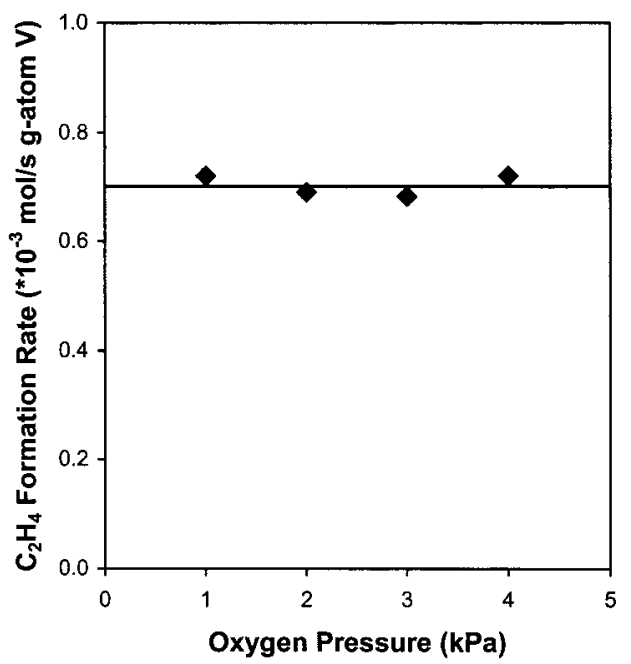

Figure 2. Effect of $\mathrm{O}_{2}$ concentration on $\mathrm{C}_{2} \mathrm{H}_{4}$ formation rate on $10 \mathrm{wt}$ $\% \mathrm{~V}_{2} \mathrm{O}_{5} / \mathrm{ZrO}_{2}\left(3.9 \mathrm{~V} / \mathrm{nm}^{2}\right)\left[3.4 \mathrm{kPa} \mathrm{C}_{2} \mathrm{H}_{6}\right.$, balance $\left.\mathrm{He}, 723 \mathrm{~K}\right]$.

with a mass selective detector (Hewlett-Packard 5872). The ion yields were analyzed using deconvolution methods that account for natural ${ }^{13} \mathrm{C}$ abundance and fragmentation patterns ${ }^{19}$ in order to obtain the ${ }^{13} \mathrm{C},{ }^{2} \mathrm{H}$, and ${ }^{18} \mathrm{O}$ isotopomer distributions in each reactant or product. $\mathrm{C}_{2} \mathrm{H}_{6}$ (Scott Specialty Gases, research grade, $>99.999 \%$ ), $\mathrm{C}_{2} \mathrm{D}_{6}$ (Isotec, chemical purity $>99 \%$, isotopic purity $>99 \%$ ), ${ }^{13} \mathrm{C}_{2} \mathrm{H}_{4}$ (Isotec, chemical purity $>99.9 \%$, isotopic purity $>99 \%$ ), ${ }^{16} \mathrm{O}_{2}$ (Praxair, research grade, chemical purity $>99.999 \%$, isotopic purity $99.92 \%$ ), ${ }^{18} \mathrm{O}_{2}$ (Isotec, chemical purity $>99 \%$, isotopic purity $>99 \%$ ), and ${ }^{2} \mathrm{H}_{2} \mathrm{O}$ (Isotec, chemical purity $100 \%$, isotopic purity $99.9 \%$ ), were used without further purification. Helium (Airgas, research grade $>99.9999 \%$ ) was used as an inert diluent.

\section{Results and Discussion}

Effects of Reactant and Product Concentrations on Reaction Rates. Figures 1, 2, and 3 show primary ethane ODH rates (from residence time data extrapolated to zero conversion) as a function of reactant and product concentrations on $10 \mathrm{wt}$ $\% \mathrm{~V}_{2} \mathrm{O}_{5} / \mathrm{ZrO}_{2}\left(3.9 \mathrm{~V} / \mathrm{nm}^{2}\right)$. Dehydrogenation rates were nearly first-order in $\mathrm{C}_{2} \mathrm{H}_{6}$ (Figure 1) and almost zero order in $\mathrm{O}_{2}$ (Figure 2 ). The addition of water decreased primary $\mathrm{C}_{2} \mathrm{H}_{6}$ dehydrogenation rates (Figure 3 ). These inhibition effects weakened with increasing $\mathrm{H}_{2} \mathrm{O}$ concentration, as also reported previously on $\mathrm{VO}_{x} / \mathrm{SiO}_{2} \cdot{ }^{10}$ Neither $\mathrm{CO}$ nor $\mathrm{CO}_{2}$ influenced primary $\mathrm{ODH}$ rates 


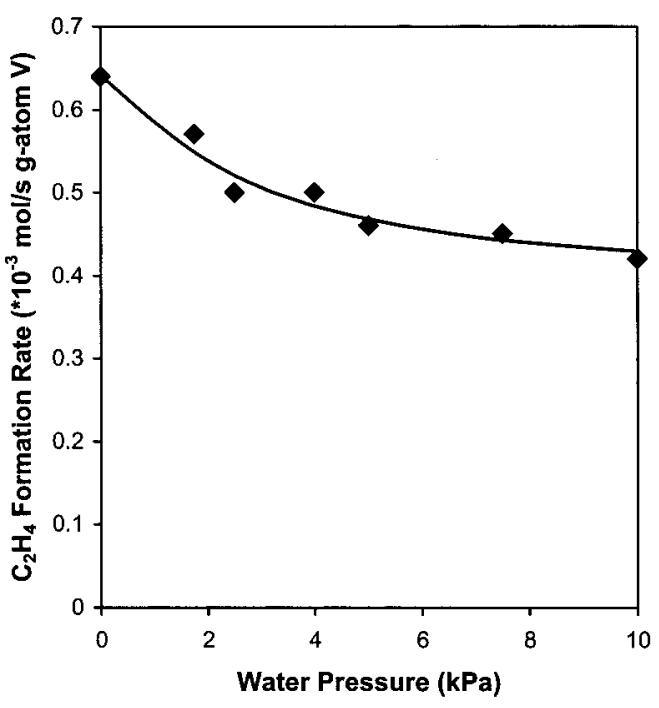

Figure 3. Effect of $\mathrm{H}_{2} \mathrm{O}$ concentration on $\mathrm{C}_{2} \mathrm{H}_{4}$ formation rate on 10 wt $\% \mathrm{~V}_{2} \mathrm{O}_{5} / \mathrm{ZrO}_{2}\left(3.9 \mathrm{~V} / \mathrm{nm}^{2}\right)\left[3.4 \mathrm{kPa} \mathrm{C}_{2} \mathrm{H}_{6}, 1.7 \mathrm{kPa} \mathrm{O}\right.$, balance $\mathrm{He}$, $723 \mathrm{~K}]$.

SCHEME 2: Sequence of Elementary Steps and Derived Rate Equation for Oxidative Dehydrogenation of Ethane on VO $x$ Catalysts

$$
\begin{aligned}
& \mathrm{C}_{2} \mathrm{H}_{6}+\mathrm{O}^{*} \stackrel{\mathrm{K}_{1}}{\Leftrightarrow} \mathrm{C}_{2} \mathrm{H}_{6} \mathrm{O}^{*} \\
& \mathrm{C}_{2} \mathrm{H}_{6} \mathrm{O}^{*}+\mathrm{O}^{*} \stackrel{\mathrm{k}_{2}}{\rightarrow} \mathrm{C}_{2} \mathrm{H}_{5} \mathrm{O}^{*}+\mathrm{OH}^{*} \\
& \mathrm{C}_{2} \mathrm{H}_{5} \mathrm{O}^{*} \stackrel{\mathrm{k}_{3}^{\prime}}{\rightarrow} \mathrm{C}_{2} \mathrm{H}_{4}+\mathrm{OH}^{*} \\
& \mathrm{OH}^{*}+\mathrm{OH}^{*} \stackrel{\mathrm{K}_{4}}{\Leftrightarrow} \mathrm{H}_{2} \mathrm{O}+\mathrm{O}^{*}+* \\
& \mathrm{O}_{2}+{ }^{*}+\stackrel{\mathrm{k}_{5}}{\rightarrow} \mathrm{O}^{*}+\mathrm{O}^{*}
\end{aligned}
$$

$$
\begin{aligned}
r_{\mathrm{C}_{2} \mathrm{H}_{4}} & =\frac{\mathrm{K}_{1} \mathrm{~K}_{2}\left[\mathrm{C}_{2} \mathrm{H}_{6}\right]}{\left\{1+\left(\left[\mathrm{H}_{2} \mathrm{O}\right] / \mathrm{K}_{4}\right)^{0.5}\left(\mathrm{~K}_{1} \mathrm{~K}_{2}\left[\mathrm{C}_{2} \mathrm{H}_{6}\right)^{0.25} /\left(2 \mathrm{~K}_{5}\left[\mathrm{O}_{2}\right]\right]^{0.25}+\left(\mathrm{K}_{1} \mathrm{~K}_{2}\left[\mathrm{C}_{2} \mathrm{H}_{6}\right]\right)^{0.5} /\left(2 \mathrm{~K}_{5}\left[\mathrm{O}_{2}\right]\right)^{0.5}\right\}^{2}\right.} \\
& =\frac{\mathrm{k}_{\text {eff }}\left[\mathrm{C}_{2} \mathrm{H}_{6}\right]}{\left\{1+\alpha\left[\mathrm{H}_{2} \mathrm{O}\right]^{0.5}\left[\mathrm{C}_{2} \mathrm{H}_{6}\right]^{0.25}\left[\mathrm{O}_{2}\right]^{0.25}+\beta\left[\mathrm{C}_{2} \mathrm{H}_{6}\right]^{0.5} /\left[\mathrm{O}_{2}\right]^{0.5}\right\}^{2}} \quad \mid 61
\end{aligned}
$$

on $\mathrm{VO}_{x} / \mathrm{ZrO}_{2}$. Similar conclusions were reached on the other $\mathrm{VO}_{x} / \mathrm{Al}_{2} \mathrm{O}_{3}$ catalysts studied, indicating that ethane $\mathrm{ODH}$ reaction orders on $\mathrm{VO}_{x}$ domains are not influenced by the support or by any changes in domain size or structure caused by changes in the support or in the $\mathrm{VO}_{x}$ surface density. Detailed kinetic measurements on $\mathrm{VO}_{x} / \mathrm{ZrO}_{2}$ and $\mathrm{VO}_{x} / \mathrm{Al}_{2} \mathrm{O}_{3}$ were consistent with ethane orders slightly smaller than one and with small positive orders in $\mathrm{O}_{2}$ concentration. This kinetic dependence reflects some subtle mechanistic details illustrated by the elementary steps in Scheme 2; it is significantly more complex than the zero and first-order respective $\mathrm{O}_{2}$ and $\mathrm{C}_{2} \mathrm{H}_{6}$ dependences widely reported for alkane ODH reactions. ${ }^{1-4}$

Scheme 2 shows a set of elementary steps consistent with this kinetic dependence and with the isotopic experiments reported below. $\mathrm{O} *$ represents a lattice oxygen $(\mathrm{O}=\mathrm{V}, \mathrm{V}-\mathrm{O}-$ $\mathrm{V}$, or $\mathrm{V}-\mathrm{O}-\mathrm{M}$, where $\mathrm{M}$ is the oxide support). $\mathrm{C}_{2} \mathrm{H}_{5} \mathrm{O}^{*}$ is an ethoxide species attached to a V-cation $\left(\mathrm{C}_{2} \mathrm{H}_{5}-\mathrm{O}-\mathrm{V}\right)$; $\mathrm{OH}^{*}$ denotes a hydroxyl group bound to $\mathrm{V}$ or $\mathrm{M}$, and $*$ is a reduced $\mathrm{V}$ center, consisting of an oxygen vacancy at a single $\mathrm{V}^{3+}$ or shared between two $\mathrm{V}^{4+}$. Step 1 represents the quasi-equilibrated weak molecular adsorption of ethane. In this Scheme, Step 2 becomes the only kinetically relevant step when $\mathrm{O} *$ is the most abundant reactive intermediate (mari). This step involves the activation of one of the six equivalent $\mathrm{C}-\mathrm{H}$ bonds in ethane using lattice oxygens to form an adsorbed ethoxide species and

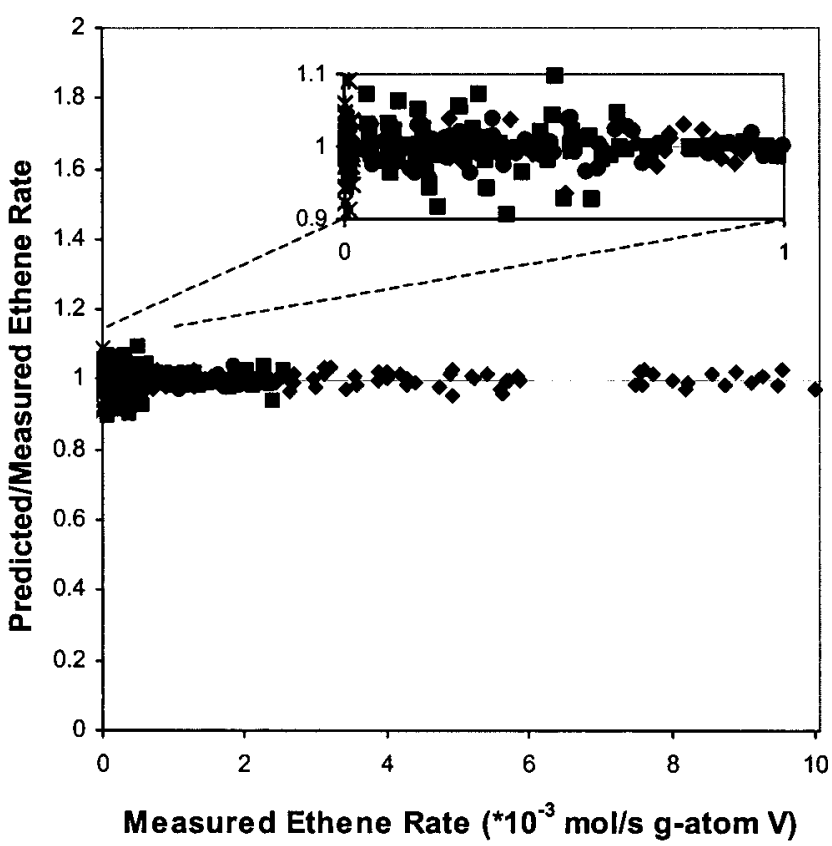

Figure 4. Predicted versus actual rates of ethane $\mathrm{ODH}$ on $\mathrm{VO}_{x} / \mathrm{Al}_{2} \mathrm{O}_{3}$ and $\mathrm{V}_{2} \mathrm{O}_{5}$ using the rate equation in Scheme 2; squares: $2 \mathrm{wt} \% \mathrm{~V}_{2} \mathrm{O}_{5} /$ $\mathrm{Al}_{2} \mathrm{O}_{3}\left(1.4 \mathrm{~V} / \mathrm{nm}^{2}\right)$; diamonds: 10 wt $\% \mathrm{~V}_{2} \mathrm{O}_{5} / \mathrm{Al}_{2} \mathrm{O}_{3}\left(8.0 \mathrm{~V} / \mathrm{nm}^{2}\right)$; circles: $30 \mathrm{wt} \% \mathrm{~V}_{2} \mathrm{O}_{5} / \mathrm{Al}_{2} \mathrm{O}_{3}\left(34 \mathrm{~V} / \mathrm{nm}^{2}\right)$; stars: unsupported $\mathrm{V}_{2} \mathrm{O}_{5}$; [3.4-14 kPa C $\left.\mathrm{H}_{6}, 1.7-6.8 \mathrm{kPa} \mathrm{O}_{2}, 663-743 \mathrm{~K}\right]$.

a $\mathrm{OH}$ group. These ethoxide species then form ethene in Step 3 , via the elimination of an $\mathrm{H}$ atom to form a second $\mathrm{OH}$ group. Step 4 involves the quasi-equilibrated recombination of two vicinal $\mathrm{OH}$ groups to form water, leaving behind an oxygen vacancy. The irreversible dissociative chemisorption of $\mathrm{O}_{2}$ (Step 5) then reoxidizes the reduced $\mathrm{V}$ centers to form the stoichiometric $\mathrm{V}^{5+}$ oxide domains required for a new catalytic cycle. This Mars-van Krevelen mechanism resembles those shown to account for propane $\mathrm{ODH}$ on $\mathrm{VO}_{x}{ }^{12}$ and $\mathrm{MoO}_{x}{ }^{14}$ catalysts.

The elementary steps shown in Scheme 2 lead to the rate equation shown in eq 6 (Scheme 2). This rate equation follows from Scheme 2 via the straightforward application of the pseudosteady-state hypothesis (PSSH) for each surface species together with the quasi-equilibrium assumption for steps 1 and 4 , and the assumption of $\mathrm{O}^{*}, \mathrm{OH}^{*}$, and $*$ as the most abundant reactive intermediates (mari). This equation accurately describes the experimental rate data, including the apparent deviations of the $\mathrm{C}_{2} \mathrm{H}_{6}$ and $\mathrm{O}_{2}$ orders from 1 and 0 , respectively, as shown by the comparison between the predictions from these equations and the measured reaction rates included in Figure 4. Thus, the mechanism shown in Scheme 2 is consistent with experimental rate measurements. Ethane ODH rates per $\mathrm{V}$ on both $2 \mathrm{wt} \%$ $\mathrm{V}_{2} \mathrm{O}_{5} / \mathrm{Al}_{2} \mathrm{O}_{3}$ and unsupported $\mathrm{V}_{2} \mathrm{O}_{5}$ (squares and stars visible in the Figure 4 inset) are very low, and they lead to less accurate flow and conversion measurements and to more scatter for these rate measurements than for those on $10 \mathrm{wt} \%$ and $30 \mathrm{wt} \%$ $\mathrm{V}_{2} \mathrm{O}_{5} / \mathrm{Al}_{2} \mathrm{O}_{3}$ catalysts.

The values of the parameters used in the ethane $\mathrm{ODH}$ rate equation (eq 6) for 10 wt $\% \mathrm{~V}_{2} \mathrm{O}_{5} / \mathrm{Al}_{2} \mathrm{O}_{3}$ (Figure 4) are given in Table 2. The ethane adsorption equilibrium constant, $K_{1}$, and the initial $\mathrm{C}-\mathrm{H}$ bond activation rate constant, $k_{2}^{\prime}$, appear as an effective rate constant $\left(k_{\text {eff }}\right)$ in the numerator of eq 6 . The values of $k_{\text {eff }}$ follow the expected Arrhenius-type magnitude increase with increasing reaction temperature. Its apparent activation energy is $110( \pm 15) \mathrm{kJ} / \mathrm{mol}$, in agreement with previous measurements on this catalyst. ${ }^{11}$ The three terms in the denominator of eq 6 reflect the relative contributions of $\mathrm{O}^{*}$, 
TABLE 2: Values of Fitted Kinetic Parameters for the Ethane ODH Rate Equation (Eq 6 in Scheme 2)

\begin{tabular}{lccccc}
\hline \multicolumn{1}{c}{ parameter } & $663 \mathrm{~K}$ & $683 \mathrm{~K}$ & $703 \mathrm{~K}$ & $723 \mathrm{~K}$ & $743 \mathrm{~K}$ \\
\hline$k_{\text {eff }}{ }^{a}\left(\mathrm{~cm}^{3} \mathrm{~mol}^{-1} \mathrm{~s}^{-1}\right)$ & 30 & 50 & 91 & 150 & 240 \\
$\alpha^{b}\left(\mathrm{~cm}^{1.5} \mathrm{~mol}^{-0.5} \mathrm{~s}^{-0.5}\right)$ & 14 & 3.3 & 0 & 0 & 0 \\
$\alpha\left[\mathrm{C}_{2} \mathrm{H}_{6}\right]^{0.25}\left[\mathrm{H}_{2} \mathrm{O}\right]^{0.5}\left[\mathrm{O}_{2}\right]^{-0.25 c}$ & 0.09 & 0.02 & 0 & 0 & 0 \\
$\quad$ typical values & & & & & \\
$\beta^{d}$ & 0.06 & 0.06 & 0.07 & 0.06 & 0.04 \\
$\beta\left[\mathrm{C}_{2} \mathrm{H}_{6}\right]^{0.5}\left[\mathrm{O}_{2}\right]^{-0.5 e}$ & 0.02 & 0.02 & 0.02 & 0.02 & 0.01 \\
$\quad$ typical values & & & & & \\
$\quad a=K_{1} k_{2 \cdot}^{\prime}{ }^{b}=K_{1}{ }^{0.25} k_{2}^{\prime}{ }^{0.25} K_{4}{ }^{-0.5} 2 k_{5}{ }^{-0.25} \cdot{ }^{c}=\left(K_{1} k_{2}^{\prime}\left[\mathrm{C}_{2} \mathrm{H}_{6}\right]\right)^{0.25}\left(\left[\mathrm{H}_{2} \mathrm{O}\right] /\right.$ \\
$\left.K_{4}\right)^{0.5}\left(2 k_{5}\left[\mathrm{O}_{2}\right]\right)^{-0.25} \cdot{ }^{d}=K_{1}{ }^{0.5} k_{2}^{\prime}{ }^{0.5} 2 k_{5}{ }^{-0.5} \cdot{ }^{e}=\left(K_{1} k_{2}^{\prime}\left[\mathrm{C}_{2} \mathrm{H}_{6}\right]\right)^{0.5}\left(2 k_{5}\left[\mathrm{O}_{2}\right]\right)^{-0.5}$.
\end{tabular}

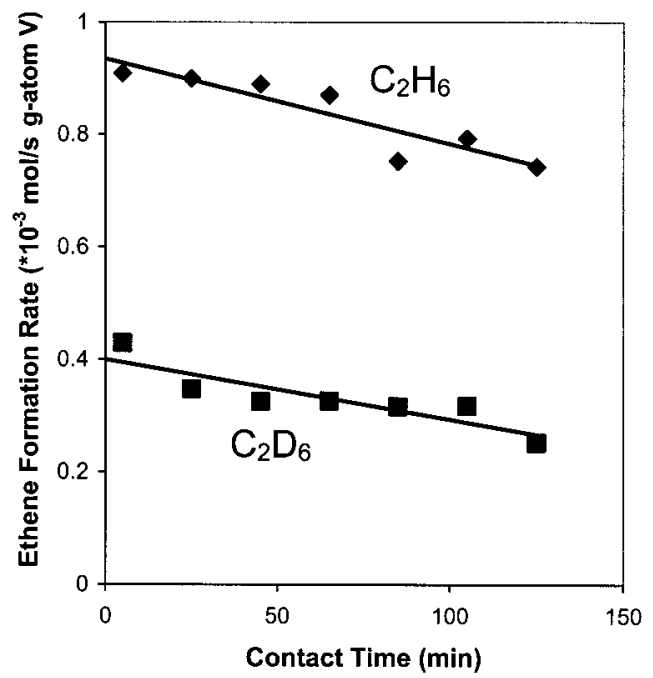

Figure 5. Ethene formation rate as a function of time during ethane $\mathrm{ODH}$ with $\mathrm{C}_{2} \mathrm{H}_{6}$ and with $\mathrm{C}_{2} \mathrm{D}_{6}$ reactants on $10 \mathrm{wt} \% \mathrm{~V}_{2} \mathrm{O}_{5} / \mathrm{Al}_{2} \mathrm{O}_{3}(8.0$ $\left.\mathrm{V} / \mathrm{nm}^{2}\right)\left[14 \mathrm{kPa} \mathrm{C}_{2} \mathrm{H}_{6}\right.$ or $\left.\mathrm{C}_{2} \mathrm{D}_{6}, 1.7 \mathrm{kPa} \mathrm{O}, 663 \mathrm{~K}\right]$.

$\mathrm{OH}^{*}$, and $*$ in the order in which they appear. Table 2 contains $\alpha$ and $\beta$, which are the collected equilibrium and rate parameters preceding the $\mathrm{OH}^{*}$ and $*$ terms, $\left(K_{1}{ }^{0.25} k_{2}^{\prime}{ }^{0.25} K_{4}{ }^{-0.5} 2 k_{5}{ }^{-0.25}\right.$ and $K_{1}^{0.5} k_{2}^{\prime}{ }^{0.5} 2 k_{5}{ }^{-0.5}$, respectively). The values of $\alpha$ and $\beta$, when multiplied by typical reactant and product concentrations, are small relative to the 1 in this denominator, suggesting that the concentrations of $\mathrm{OH}^{*}$ and $*$ are small compared to that of $\mathrm{O}^{*}$. The calculated values for $\mathrm{OH}^{*}$ and $*$ are qualitatively consistent with our recent in situ measurements of the number reduced vanadia centers using UV-vis spectroscopy, which suggest that $<\sim 5 \%$ of the vanadium atoms are reduced during steady-state alkane ODH reactions. ${ }^{20}$ At low reaction temperatures, the value of $\alpha$ leads to $\mathrm{OH}^{*}$ surface coverage estimates of $\sim 8 \%$, which are consistent with the mild inhibition effects of water observed on ethane ODH rates (Figure 3). These inhibition effects weaken with increasing temperature because of the exothermic nature of the water adsorption step, which titrates vacancy sites (*) with $\mathrm{OH}^{*}$ and decreases the number of lattice oxygen atoms $\left(\mathrm{O}^{*}\right)$ available for kinetically relevant $\mathrm{C}-\mathrm{H}$ bond activation steps.

Isotopic Tracer Studies and Kinetic Isotopic Effects. The kinetic significance and reversibility of the elementary steps shown in Scheme 2 and the role of lattice oxygen atoms in $\mathrm{C}-\mathrm{H}$ bond activation were probed using reactants and products labeled with ${ }^{2} \mathrm{H},{ }^{13} \mathrm{C}$, or ${ }^{18} \mathrm{O}$. Kinetic isotope effects were measured from separate reactions of $\mathrm{C}_{2} \mathrm{H}_{6}-\mathrm{O}_{2}$ and $\mathrm{C}_{2} \mathrm{D}_{6}-\mathrm{O}_{2}$ reactant mixtures (14 $\mathrm{kPa}$ ethane; $1.7 \mathrm{kPa} \mathrm{O}_{2}$ ) on $10 \mathrm{wt} \% \mathrm{~V}_{2} \mathrm{O}_{5} / \mathrm{Al}_{2} \mathrm{O}_{3}$. Several of these experiments were repeated on $10 \mathrm{wt} \% \mathrm{~V}_{2} \mathrm{O}_{5} / \mathrm{ZrO}_{2}$, with similar conclusions.

Figure 5 shows ethene formation rates from $\mathrm{C}_{2} \mathrm{H}_{6}-\mathrm{O}_{2}$ and $\mathrm{C}_{2} \mathrm{D}_{6}-\mathrm{O}_{2}$ mixtures at $663 \mathrm{~K}$ as a function of reactor residence
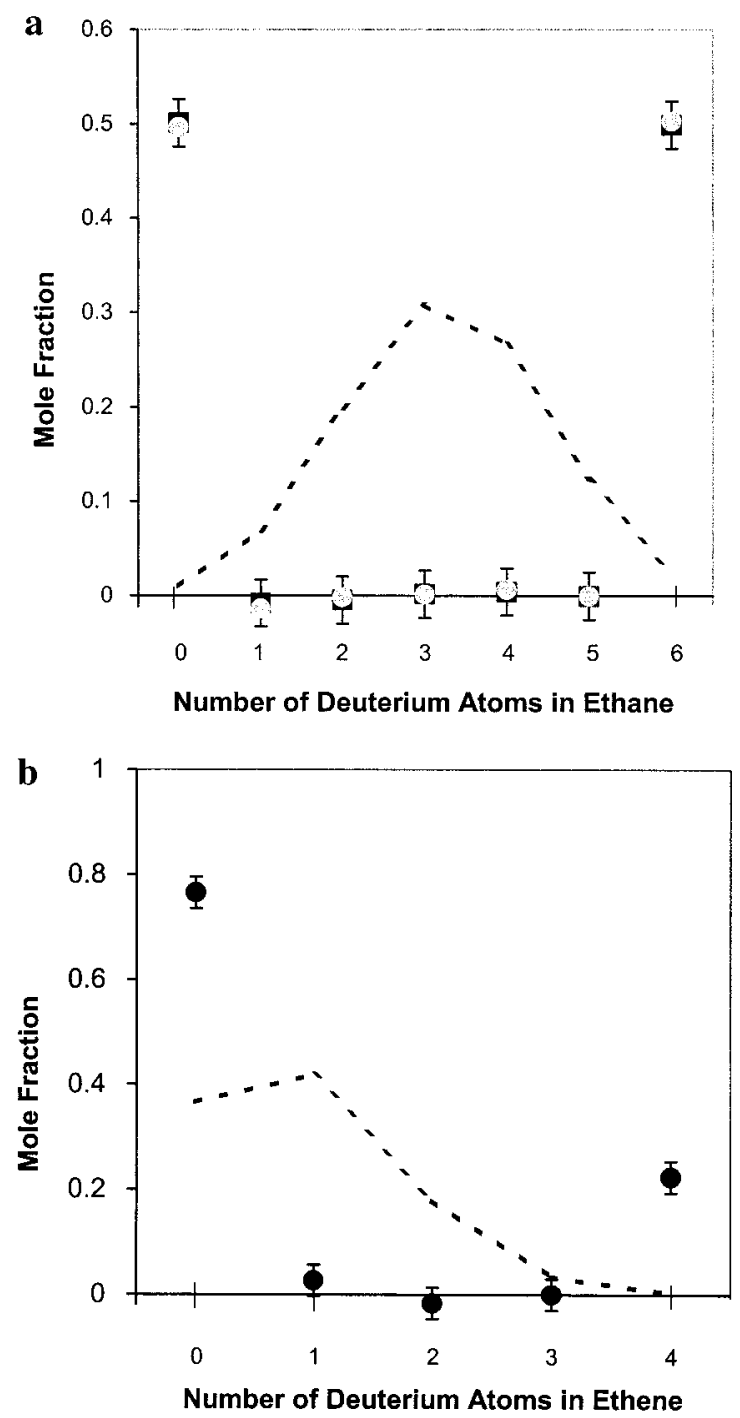

Figure 6. a. Deuterium distribution in ethane during $\mathrm{ODH}$ of $\mathrm{C}_{2} \mathrm{H}_{6}-$ $\mathrm{C}_{2} \mathrm{D}_{6}-\mathrm{O}_{2}$ mixtures on 10 wt $\% \mathrm{~V}_{2} \mathrm{O}_{5} / \mathrm{Al}_{2} \mathrm{O}_{3}\left(8.0 \mathrm{~V} / \mathrm{nm}^{2}\right)$; squares: starting mixture; circles: $2.5 \mathrm{~h}$ reaction time, $4.4 \%$ ethane conversion; dashed line represents binomial distribution $\left[6.8 \mathrm{kPa} \mathrm{C}_{2} \mathrm{H}_{6}, 6.8 \mathrm{kPa}\right.$ $\mathrm{C}_{2} \mathrm{D}_{6}, 1.7 \mathrm{kPa} \mathrm{O}, 663 \mathrm{~K}$, recirculating batch reactor]. b. Deuterium distribution in ethene formed from $\mathrm{C}_{2} \mathrm{H}_{6}-\mathrm{C}_{2} \mathrm{D}_{6}-\mathrm{O}_{2}$ mixtures on 10 wt $\% \quad \mathrm{~V}_{2} \mathrm{O}_{5} / \mathrm{Al}_{2} \mathrm{O}_{3}\left(8.0 \mathrm{~V} / \mathrm{nm}^{2}\right)$; dashed line represents binomial distribution $\left[6.8 \mathrm{kPa} \mathrm{C}_{2} \mathrm{H}_{6}, 6.8 \mathrm{kPa} \mathrm{C}_{2} \mathrm{D}_{6}, 1.7 \mathrm{kPa} \mathrm{O}, 663 \mathrm{~K}\right.$, recirculating batch reactor, $2.5 \mathrm{~h}$ reaction time, $4.4 \%$ ethane conversion].

time. The primary $\mathrm{C}_{2} \mathrm{H}_{6}$ dehydrogenation rate constant $\left(k_{1 \mathrm{H}}\right)$ obtained from these data is 2.4 times larger than the rate constant for $\mathrm{C}_{2} \mathrm{D}_{6}$ dehydrogenation $\left(k_{1 \mathrm{D}}\right)$. This normal kinetic isotope effect (KIE) is consistent with kinetically relevant $\mathrm{C}-\mathrm{H}$ bond activation steps (Step 2 in Scheme 2), as assumed in most previous studies. ${ }^{1-5,8,12}$ The KIE for each of the reactions in Scheme 1 is discussed in greater detail below. At $<3 \%$ ethane conversion, the rates of ethene formation presented in Figure 5 decreased with increasing contact time to an extent much greater than expected from the slight depletion of the ethane reactants. This decrease in the net rate of ethene formation reflects the combustion (via Reaction 3 in Scheme 1) of some of the ethene formed in primary ODH steps, as well as a weak inhibition of ethane ODH rates by the water formed in ODH and combustion steps (Figure 3).

$\mathrm{A} \mathrm{C}_{2} \mathrm{H}_{6}-\mathrm{C}_{2} \mathrm{D}_{6}-\mathrm{O}_{2}(6.8-6.8-1.7 \mathrm{kPa})$ mixture was used in order to examine the reversibility of $\mathrm{C}-\mathrm{H}$ bond activation steps (Step 2). $\mathrm{C}_{2} \mathrm{H}_{6-x} \mathrm{D}_{x}$ isotopomers would be expected to form if this step were reversible. Figure 6 a shows that equimolar $\mathrm{C}_{2} \mathrm{H}_{6}-$ 
$\mathrm{C}_{2} \mathrm{D}_{6}$ reactant mixtures did not lead to detectable amounts of mixed $\mathrm{C}_{2} \mathrm{H}_{6-x} \mathrm{D}_{x}$ isotopomers, consistent with irreversible $\mathrm{C}-\mathrm{H}$ bond activation steps. Mathematical instabilities in the matrix inversion procedures used to calculate isotopomer distributions and weak secondary kinetic isotope effects in mass fragmentation patterns lead to the observed scatter in isotopomer concentrations (around zero) and to slightly negative values for some of the mixed isotopomers. No mixed isotopomers of ethene $\left(\mathrm{C}_{2} \mathrm{H}_{4-x} \mathrm{D}_{x}\right)$ were detected (Figure $6 \mathrm{~b}$ ), indicating that hydrogen abstraction steps in ethoxide groups (to form ethene) are also irreversible and that the reversible readsorption of ethene on $\mathrm{OH}^{*}$, via the microscopic reverse of ethene formation from ethoxide species, is slow relative to ethane ODH turnovers. It appears that the readsorption of ethene on $\mathrm{O}^{*}$ sites and the concomitant $\mathrm{C}-\mathrm{H}$ bond activation required for secondary ethene reactions to form $\mathrm{CO}_{x}$ are also irreversible and that the cleavage of the first $\mathrm{C}-\mathrm{H}$ bond in ethene leads to rapid cascade reactions leading to the ultimate desorption of $\mathrm{CO}$ and $\mathrm{CO}_{2}$. The amount of $\mathrm{C}_{2} \mathrm{H}_{4}$ formed is larger than that of $\mathrm{C}_{2} \mathrm{D}_{4}$ for equimolar $\mathrm{C}_{2} \mathrm{H}_{6}-$ $\mathrm{C}_{2} \mathrm{D}_{6}$ reactant mixtures because normal kinetic isotope effects favor ODH reactions of $\mathrm{C}_{2} \mathrm{H}_{6}$ over those of $\mathrm{C}_{2} \mathrm{D}_{6}$ (by a factor of 2.4).

$\mathrm{A} \mathrm{C}_{2} \mathrm{H}_{6}-\mathrm{O}_{2}-\mathrm{D}_{2} \mathrm{O}(13.5-1.7-0.5 \mathrm{kPa})$ reactant mixture was used in order to confirm the irreversibility of Steps 2 and 3 and to determine the extent to which $\mathrm{OH}^{*}$ recombination steps leading to $\mathrm{H}_{2} \mathrm{O}$ desorption (Step 4) are reversible. Neither $\mathrm{C}_{2} \mathrm{H}_{6-x} \mathrm{D}_{x}$ nor $\mathrm{C}_{2} \mathrm{H}_{4-x} \mathrm{D}_{x}$ were detected (Figure $7 \mathrm{a}$ and $7 \mathrm{~b}$ ), consistent with irreversible $\mathrm{C}-\mathrm{H}$ bond activation steps in both ethane and ethene molecules. A binomial distribution of $\mathrm{H}_{2} \mathrm{O}$, $\mathrm{HDO}$, and $\mathrm{D}_{2} \mathrm{O}$ isotopomers indicates that quasi-equilibrium between $\mathrm{OH}^{*}$ and $\mathrm{H}_{2} \mathrm{O}_{(\mathrm{g})}$ is achieved during ethane $\mathrm{ODH}$ reactions. Previous studies using $\mathrm{C}_{3} \mathrm{H}_{8}-\mathrm{O}_{2}-\mathrm{D}_{2} \mathrm{O}$ mixtures have also concluded that water desorption steps are reversible, ${ }^{12}$ but rapid isotopic exchange unrelated to propane dehydrogenation steps prevented a definite assessment of the extent of reversibility. $\mathrm{OH}$ recombination steps must be reversible for $\mathrm{H}_{2} \mathrm{O}$ to be able to inhibit ODH rates, as observed for propane ${ }^{12-14}$ and ethane (Figure 3 ) reactions. Irreversible $\mathrm{H}_{2} \mathrm{O}$ desorption steps would prevent gas-phase $\mathrm{H}_{2} \mathrm{O}$ molecules from influencing the surface concentration of any adsorbed intermediates or the rate of any surface reactions.

Figure $8 \mathrm{a}$ shows the ${ }^{18} \mathrm{O}$ isotopic content in the water formed from $\mathrm{C}_{2} \mathrm{H}_{6}-{ }^{18} \mathrm{O}_{2}-{ }^{16} \mathrm{O}_{2}$ reactant mixtures on a $\mathrm{VO}_{x} / \mathrm{Al}_{2} \mathrm{O}_{3}(10$ wt $\% \mathrm{~V}_{2} \mathrm{O}_{5}, 8.0 \mathrm{~V} / \mathrm{nm}^{2}$ ) sample containing only ${ }^{16} \mathrm{O}$. The initial $\mathrm{H}_{2} \mathrm{O}$ products formed contained predominately ${ }^{16} \mathrm{O}$ from the $\mathrm{VO}_{x}$ lattice and only trace amounts of ${ }^{18} \mathrm{O}$ from the ${ }^{18} \mathrm{O}_{2}-{ }^{16} \mathrm{O}_{2}$ equimolar reactant mixture. This suggests that lattice oxygen is involved in the activation of $\mathrm{C}-\mathrm{H}$ bonds in ethane and in the primary formation of water via Step 4 (in Scheme 2). As catalytic turnovers occur, lattice ${ }^{16} \mathrm{O}$ is gradually removed as $\mathrm{H}_{2}{ }^{16} \mathrm{O}$ and replaced with equimolar amounts of ${ }^{18} \mathrm{O}$ and ${ }^{16} \mathrm{O}$ from $\mathrm{O}_{2}$ via the filling of vacancies in Step 5 (Scheme 2). As a result, the $\mathrm{H}_{2}{ }^{16} \mathrm{O} / \mathrm{H}_{2}{ }^{18} \mathrm{O}$ ratio increases with reaction time and approaches the value of unity expected from the equimolar amounts of ${ }^{18} \mathrm{O}$ and ${ }^{16} \mathrm{O}$ atoms in the reactant stream (Figure 8a). These conclusions, however, are not unequivocal, because the reversibility of water formation steps (Step 4) can lead to rapid isotopic exchange of any $\mathrm{H}_{2} \mathrm{O}$ formed with the pool of lattice ${ }^{16} \mathrm{O}$ pool via the reverse of Step 4.

$\mathrm{No}{ }^{18} \mathrm{O}^{16} \mathrm{O}$ isotopomers were detected in the reactor effluent at any conversion or contact time (Figure 8a) during reactions of $\mathrm{C}_{2} \mathrm{H}_{6}-{ }^{18} \mathrm{O}_{2}-{ }^{16} \mathrm{O}_{2}$ reactant mixtures. Reversible $\mathrm{O}_{2}$ dissociation steps (Step 5) would lead to mixed dioxygen isotopomers, as the recombination of lattice oxygen species occurs more
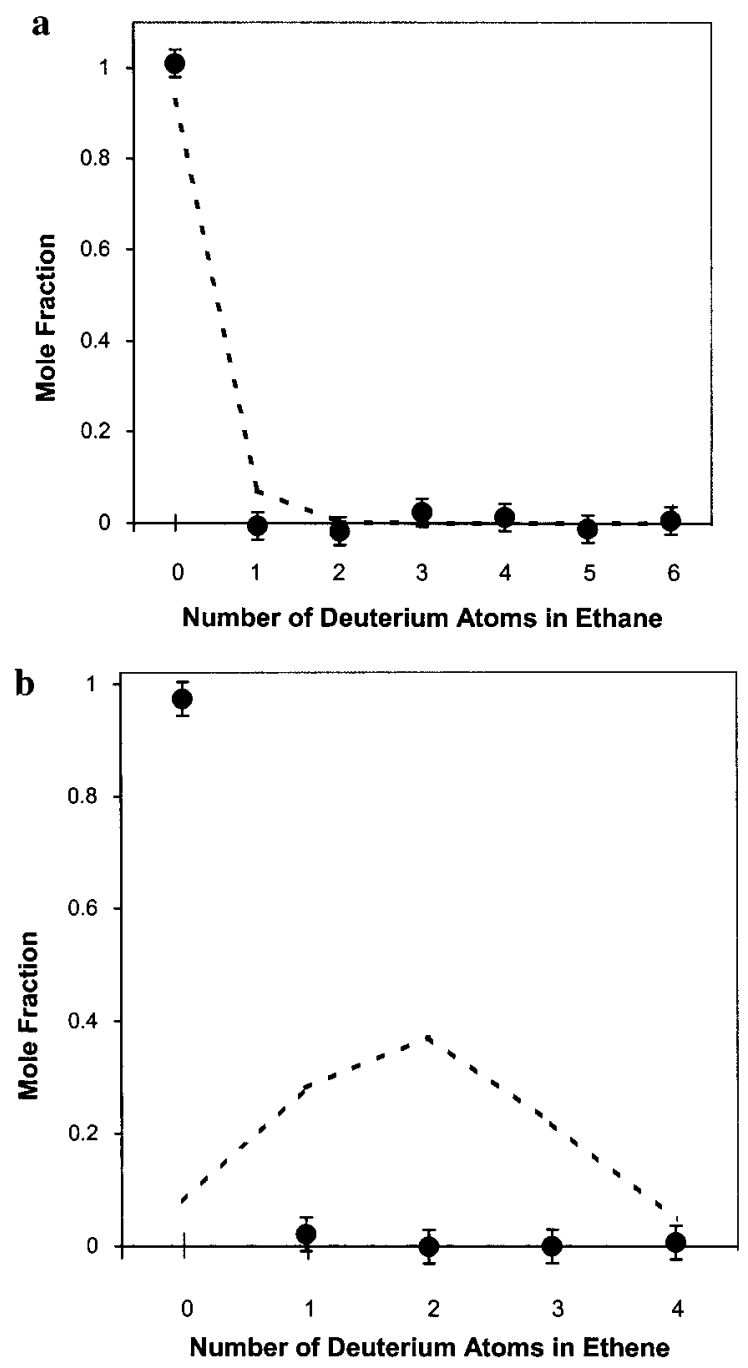

Figure 7. a. Deuterium distribution in ethane during reaction of $\mathrm{C}_{2} \mathrm{H}_{6}-$ $\mathrm{O}_{2}-\mathrm{D}_{2} \mathrm{O}$ mixtures on $10 \mathrm{wt} \% \mathrm{~V}_{2} \mathrm{O}_{5} / \mathrm{Al}_{2} \mathrm{O}_{3}\left(8.0 \mathrm{~V} / \mathrm{nm}^{2}\right)$; dashed line represents binomial distribution $\left[14 \mathrm{kPa} \mathrm{C}_{2} \mathrm{H}_{6}, 1.7 \mathrm{kPa} \mathrm{O}, 0.5 \mathrm{kPa}\right.$ $\mathrm{D}_{2} \mathrm{O}, 663 \mathrm{~K}$, recirculating batch reactor, $3.1 \mathrm{~h}$ reaction time, $2.8 \%$ ethane conversion]. b. Deuterium distribution in ethene formed from $\mathrm{C}_{2} \mathrm{H}_{6}-$ $\mathrm{O}_{2}-\mathrm{D}_{2} \mathrm{O}$ mixtures on 10 wt $\% \mathrm{~V}_{2} \mathrm{O}_{5} / \mathrm{Al}_{2} \mathrm{O}_{3}\left(8.0 \mathrm{~V} / \mathrm{nm}^{2}\right)$; dashed line represents binomial distribution $\left[14 \mathrm{kPa} \mathrm{C}_{2} \mathrm{H}_{6}, 1.7 \mathrm{kPa} \mathrm{O}, 0.5 \mathrm{kPa}\right.$ $\mathrm{D}_{2} \mathrm{O}, 663 \mathrm{~K}$, recirculating batch reactor, $3.1 \mathrm{~h}$ reaction time, $2.8 \%$ ethane conversion].

rapidly than ODH turnovers. Thus, as also shown for propane ODH reactions on $\mathrm{VO}_{x}{ }^{12,13}$ and $\mathrm{MoO}_{x},{ }^{13} \mathrm{O}_{2}$ dissociation steps are irreversible during ethane $\mathrm{ODH}$ on $\mathrm{VO}_{x}$-based catalysts.

Figure $8 \mathrm{~b}$ shows the ${ }^{18} \mathrm{O} /{ }^{16} \mathrm{O}$ isotopic ratio in the $\mathrm{H}_{2} \mathrm{O}, \mathrm{CO}$, and $\mathrm{CO}_{2}$ formed from the $\mathrm{C}_{2} \mathrm{H}_{6}-{ }^{18} \mathrm{O}_{2}-{ }^{16} \mathrm{O}_{2}$ reactant mixture. $\mathrm{CO}$ and $\mathrm{CO}_{2}$ also contain only ${ }^{16} \mathrm{O}$ during the initial stages of the reaction, confirming that lattice oxygen is also involved in primary and secondary combustion reactions. The distribution of ${ }^{18} \mathrm{O}$ in the $\mathrm{CO}_{2}$ is binomial, indicating that statistical sampling of lattice oxygen atoms occurs during $\mathrm{CO}_{2}$ formation. The ${ }^{18} \mathrm{O}$ contents in $\mathrm{H}_{2} \mathrm{O}, \mathrm{CO}$, and $\mathrm{CO}_{2}$ are similar and increase concurrently with increasing reaction time as the lattice reaches equilibrium with the equimolar ${ }^{16} \mathrm{O}_{2}-{ }^{18} \mathrm{O}_{2}$ reactant mixture and ultimately provides lattice ${ }^{18} \mathrm{O}$ and ${ }^{16} \mathrm{O}$ atoms with equal probability for both primary and secondary products. ODH and combustion reactions appear to sample the same lattice oxygen pool, suggesting that similar sites are involved in $\mathrm{ODH}$ and combustion reactions.

A reactant mixture consisting of $\mathrm{C}_{2} \mathrm{H}_{6}(14 \mathrm{kPa}),{ }^{13} \mathrm{C}_{2} \mathrm{H}_{4}(0.5$ $\mathrm{kPa})$, and $\mathrm{O}_{2}(1.7 \mathrm{kPa})$ was used in order to measure the relative 

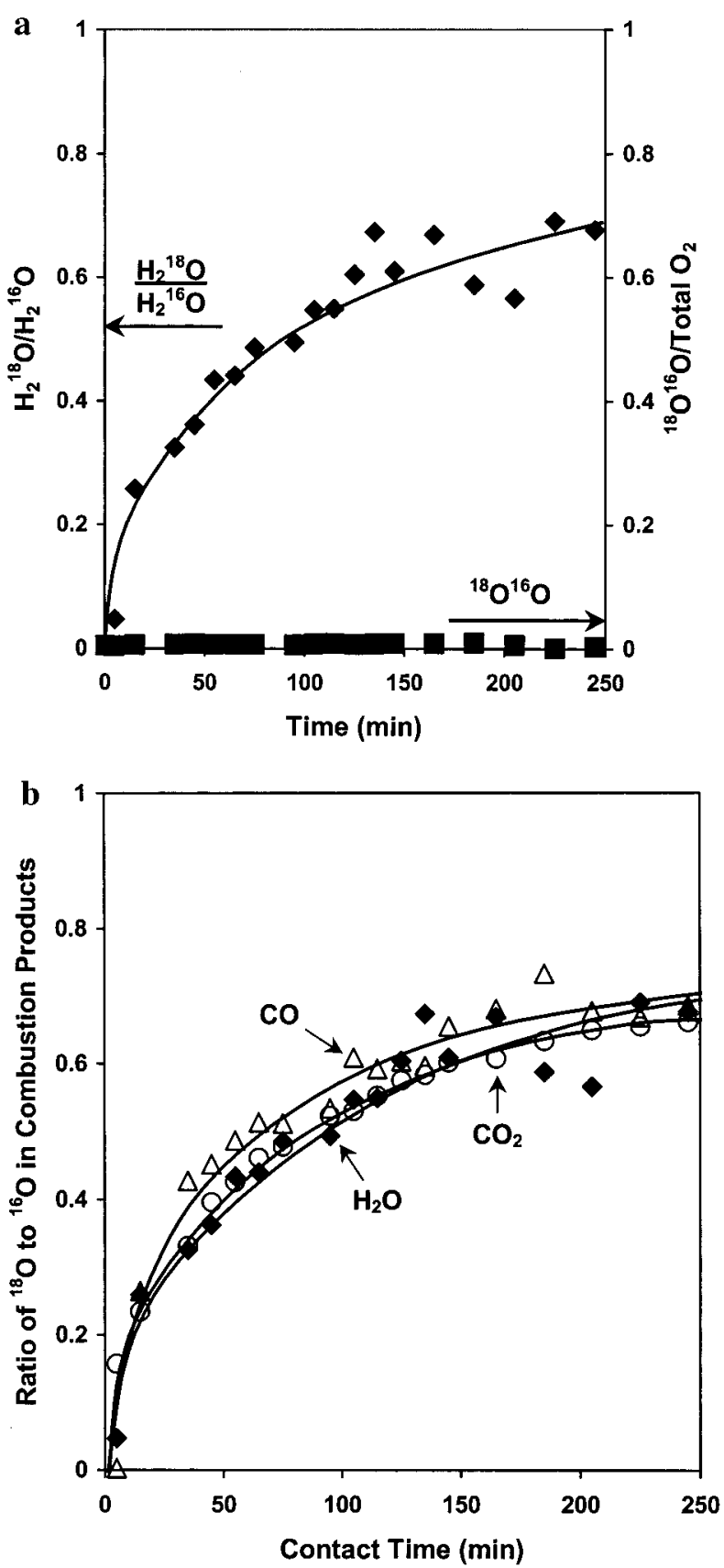

Figure 8. a. The time evolution of the $\mathrm{H}_{2}{ }^{18} \mathrm{O} / \mathrm{H}_{2}{ }^{16} \mathrm{O}$ ratio in the water product and of the ${ }^{18} \mathrm{O}^{16} \mathrm{O}$ fraction in the $\mathrm{O}_{2}$ reactant during the reaction of ethane and a mixture of ${ }^{16} \mathrm{O}_{2}-{ }^{18} \mathrm{O}_{2}$ on $10 \mathrm{wt} \% \mathrm{~V}_{2}{ }^{16} \mathrm{O}_{5} / \mathrm{Al}_{2}{ }^{16} \mathrm{O}_{3}[14$ $\mathrm{kPa} \mathrm{C}_{2} \mathrm{H}_{6}, 0.85 \mathrm{kPa}{ }^{16} \mathrm{O}_{2}, 0.85 \mathrm{kPa}{ }^{18} \mathrm{O}_{2}, 663 \mathrm{~K}$, recirculating batch reactor]. $\mathbf{b}$. The time evolution of the ${ }^{18} \mathrm{O} /{ }^{16} \mathrm{O}$ content of all combustion products from the reaction of ethane and a mixture of ${ }^{16} \mathrm{O}_{2}-{ }^{18} \mathrm{O}_{2}$ on 10 wt $\% \mathrm{~V}_{2}{ }^{16} \mathrm{O}_{5} / \mathrm{Al}_{2}{ }^{16} \mathrm{O}_{3}\left[14 \mathrm{kPa} \mathrm{C}_{2} \mathrm{H}_{6}, 0.85 \mathrm{kPa}{ }^{16} \mathrm{O}_{2}, 0.85 \mathrm{kPa}{ }^{18} \mathrm{O}_{2}\right.$, $663 \mathrm{~K}$, recirculating batch reactor].

rates of primary and secondary reactions and the reversibility of the overall ethane dehydrogenation reaction at $663 \mathrm{~K}$ on $\mathrm{VO}_{x} /$ $\mathrm{Al}_{2} \mathrm{O}_{3}$ (10 wt $\%, 8.0 \mathrm{~V} / \mathrm{nm}^{2}$ ). These competitive reactions of $\mathrm{C}_{2} \mathrm{H}_{6}$ and ${ }^{13} \mathrm{C}_{2} \mathrm{H}_{4}$ showed that $\mathrm{CO}$ and $\mathrm{CO}_{2}$ form via direct ethane combustion and secondary ethene combustion reactions. The $\mathrm{CO}$ and $\mathrm{CO}_{2}$ formed from $\mathrm{C}_{2} \mathrm{H}_{6}-{ }^{13} \mathrm{C}_{2} \mathrm{H}_{4}-\mathrm{O}_{2}$ mixtures showed similar ${ }^{13} \mathrm{C}$ contents at all contact times (Figure 9), suggesting that $\mathrm{CO}$ and $\mathrm{CO}_{2}$ form from both $\mathrm{C}_{2} \mathrm{H}_{6}$ and ${ }^{13} \mathrm{C}_{2} \mathrm{H}_{4}$. The initial concentration of ${ }^{12} \mathrm{C}_{2} \mathrm{H}_{6}$ is 27 times greater than that of ${ }^{13} \mathrm{C}_{2} \mathrm{H}_{4}$, but the initial ${ }^{13} \mathrm{C}$ fraction in $\mathrm{CO}_{x}$ combustion products, which form from essentially unscrambled reactants, is 0.47 , indicating that rate constants of $\mathrm{C}_{2} \mathrm{H}_{4}$ combustion ( $k_{3}$

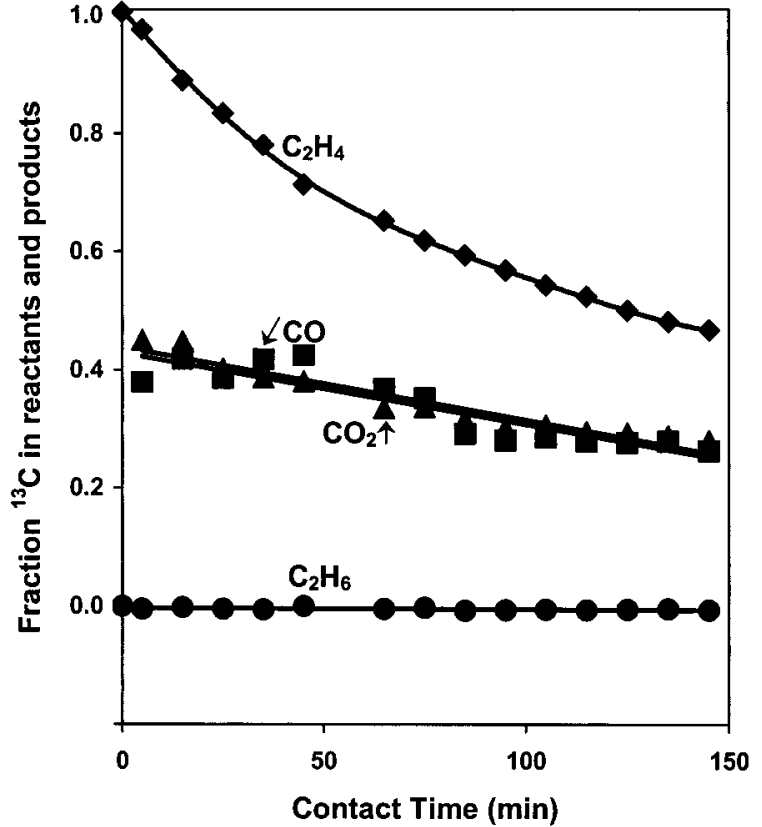

Figure 9. ${ }^{13} \mathrm{C}$ content of products during ethane $\mathrm{ODH}$, with ${ }^{13} \mathrm{C}_{2} \mathrm{H}_{4}$ initially present, on $10 \% \mathrm{VO}_{x} / \mathrm{Al}_{2} \mathrm{O}_{3}, 8.0 \mathrm{~V} / \mathrm{nm}^{2}\left[14 \mathrm{kPa} \mathrm{C}_{2} \mathrm{H}_{6}, 1.7 \mathrm{kPa}\right.$ $\mathrm{O}_{2}, 0.5 \mathrm{kPa}{ }^{13} \mathrm{C}_{2} \mathrm{H}_{4}, 663 \mathrm{~K}$, recirculating batch reactor].

TABLE 3: Reaction Rate Constant $k_{1}, k_{2}$, and $k_{3}\left(\mathrm{~cm}^{3} \mathrm{~mol}^{-1}\right.$ $\mathrm{s}^{-1}$ ) and Kinetic Isotope Effects on $10 \mathrm{wt} \% \mathrm{VO}_{x} / \mathrm{Al}_{2} \mathrm{O}_{3}$ Catalysts $\left(14 \mathrm{kPa} \mathrm{C}_{2} \mathrm{H}_{6}\right.$ or $14 \mathrm{KPa} \mathrm{C}_{2} \mathrm{D}_{6}, 1.7 \mathrm{KPa} \mathrm{O}_{2}$, Balance He, $663 \mathrm{~K}$ )

\begin{tabular}{lccc}
\hline & $\begin{array}{c}\text { ethane } \\
\text { dehydrogenation } \\
\left(k_{1}\right)\end{array}$ & $\begin{array}{c}\text { ethane } \\
\text { combustion } \\
\left(k_{2}\right)\end{array}$ & $\begin{array}{c}\text { ethene } \\
\text { combustion } \\
\left(k_{3}\right)\end{array}$ \\
\hline$k_{\mathrm{i}, \mathrm{C}-\mathrm{H}}$ & 30 & 10 & 170 \\
$k_{\mathrm{i}, \mathrm{C}-\mathrm{D}}$ & 12 & 5.3 & 61 \\
$k_{\mathrm{i}, \mathrm{C}-\mathrm{H}} / k_{\mathrm{i}, \mathrm{C}-\mathrm{D}}$ & 2.4 & 1.9 & 2.8
\end{tabular}

in Scheme 1) are significantly larger than for $\mathrm{C}_{2} \mathrm{H}_{6}$ combustion $\left(k_{2}\right.$ in Scheme 1) $\left(k_{3} / k_{2}=14\right)$. The ${ }^{13} \mathrm{C}$ content in $\mathrm{CO}_{x}$ decreases with increasing contact time because unlabeled ethene formed from ${ }^{12} \mathrm{C}_{2} \mathrm{H}_{6}$ dilutes the isotopically pure ${ }^{13} \mathrm{C}_{2} \mathrm{H}_{4}$ reactants initially present. A kinetic analysis of these data shows that $k_{3}$ is 5.8 times greater than the rate constant of ethene formation ( $k_{1}$ in Scheme 1 ). The $k_{2} / k_{1}$ ratio is 0.36 , indicating a primary $\mathrm{C}_{2} \mathrm{H}_{4}$ selectivity of $74 \%$. Both ratios agree with values of these rate constants obtained from the effects of reactor residence time on reaction rate and product selectivity in a flow reactor. ${ }^{11}$ The value of $k_{3} / k_{2}$ obtained from the latter measurements was 16 (11), in excellent agreement with the value of 14 reported here from isotopic tracer studies. Figure 9 shows that no ${ }^{13} \mathrm{C}$ is detected in ethane even at ethane conversions of $4.4 \%$, confirming the irreversible nature of $\mathrm{C}-\mathrm{H}$ bond activation steps, also shown from $\mathrm{C}_{2} \mathrm{H}_{6}-\mathrm{C}_{2} \mathrm{D}_{6}-\mathrm{O}_{2}$ (Figure 6) and $\mathrm{C}_{2} \mathrm{H}_{6}-\mathrm{O}_{2}-\mathrm{D}_{2} \mathrm{O}$ (Figure 7) experiments.

H-D Kinetic Isotope Effects for Primary and Secondary Reactions. Kinetic isotope effects (KIE) measured from reactions of $\mathrm{C}_{2} \mathrm{H}_{6}-\mathrm{O}_{2}$ and $\mathrm{C}_{2} \mathrm{D}_{6}-\mathrm{O}_{2}$ mixtures are shown in Table 3 for each reaction step in Scheme 1. Primary dehydrogenation $\left(k_{1}\right)$, primary combustion $\left(k_{2}\right)$, and secondary combustion $\left(k_{3}\right)$ rate constants were extracted from these rate data as a function of reaction time on $10 \mathrm{wt} \% \mathrm{~V}_{2} \mathrm{O}_{5} / \mathrm{Al}_{2} \mathrm{O}_{3}$ at $663 \mathrm{~K}$. As noted earlier (Figure 5), the kinetic isotope effect for ethane conversion to ethene $\left(k_{1 \mathrm{H}} / k_{1 \mathrm{D}}\right)$ is 2.4 , as expected for kinetically relevant steps involving $\mathrm{C}-\mathrm{H}$ bond cleavage. The corresponding kinetic isotope effects are 1.9 for ethane combustion to $\mathrm{CO}$ and $\mathrm{CO}_{2}$ $\left(k_{2 \mathrm{H}} / k_{2 \mathrm{D}}\right)$ and 2.8 for ethene combustion $\left(k_{3 \mathrm{D}} / k_{3 \mathrm{H}}\right)$. These normal 
KIE are similar for all three steps, suggesting that $\mathrm{C}-\mathrm{H}$ bond activation is a common requirement and a kinetically relevant step for all three reactions. These conclusions are reasonable in view of the similar site requirements exhibited by these primary and secondary pathways. ${ }^{1-4,11}$

The KIE values reported here for ethane and ethene reactions resemble those reported recently for propane and propene reactions on $\mathrm{VO}_{x} / \mathrm{ZrO}_{2} \cdot{ }^{12,14}$ For propane and propene reactions, KIE values were $2.5-2.8$ for $k_{1 \mathrm{H}} / k_{1 \mathrm{D}}, 1.7-1.9$ for $k_{2 \mathrm{H}} / k_{2 \mathrm{D}}$, and $2.2-2.6$ for $k_{3 \mathrm{D}} / k_{3 \mathrm{H}}$, all of which resemble the values reported here for $\mathrm{C}_{2}$ reactions.

The different KIE values measured for alkane $\mathrm{ODH}$, alkane combustion, and alkene combustion (for both $\mathrm{C}_{2}$ and $\mathrm{C}_{3}$ ) reflect the different extent to which the $\mathrm{C}-\mathrm{H}$ bond is cleaved and the $\mathrm{O}-\mathrm{H}$ and $\mathrm{O}-\mathrm{C}$ bonds are formed in the transition state required for the $\mathrm{C}-\mathrm{H}$ activation steps involved in each reaction. In the absence of concerted formation of $\mathrm{O}-\mathrm{H}$ and $\mathrm{O}-\mathrm{C}$ bonds using lattice oxygen atoms, KIE values would approach $\sim 6$ for ethane at $663 \mathrm{~K} .{ }^{14} \mathrm{KIE}$ values decrease when concerted formation of $\mathrm{O}-\mathrm{H}$ or $\mathrm{O}-\mathrm{D}$ bonds compensates in part for the higher bond energy of $\mathrm{C}-\mathrm{D}$ bonds relative to $\mathrm{C}-\mathrm{H}$ bonds. It appears that the involvement of lattice oxygen in the formation of transition states for alkane combustion is more extensive than for alkane $\mathrm{ODH}$ or alkene combustion, suggesting the involvement of specific lattice oxygen atoms with a somewhat higher affinity and reactivity for the formation of $\mathrm{O}-\mathrm{H}$ bonds during $\mathrm{C}-\mathrm{H}$ bond activation.

\section{Conclusions}

Oxidative dehydrogenation of ethane on $\mathrm{VO}_{x} / \mathrm{Al}_{2} \mathrm{O}_{3}$ and $\mathrm{VO}_{x} /$ $\mathrm{ZrO}_{2}$ occurs via parallel and sequential reactions, with ethene as the most abundant primary product. The assumption that surface oxygen, $\mathrm{OH}$ groups, and vacancies are the most abundant reactive intermediates leads to a rate equation that accurately describes measured ethane $\mathrm{ODH}$ reaction rates. The dependencies of these rates on $\mathrm{C}_{2} \mathrm{H}_{6}, \mathrm{O}_{2}$, and $\mathrm{H}_{2} \mathrm{O}$ concentrations are identical on supported $\mathrm{VO}_{x}$ and $\mathrm{V}_{2} \mathrm{O}_{5}$ powders, suggesting that similar active centers are present on both surfaces. $\mathrm{C}_{2} \mathrm{H}_{6}-\mathrm{C}_{2} \mathrm{D}_{6}$ and $\mathrm{C}_{2} \mathrm{H}_{6}-\mathrm{D}_{2} \mathrm{O}$ reactants undergo $\mathrm{ODH}$ reactions without forming $\mathrm{C}_{2} \mathrm{H}_{6-x} \mathrm{D}_{x}$ or $\mathrm{C}_{2} \mathrm{H}_{4-x} \mathrm{D}_{x}$ mixed isotopomers, suggesting that $\mathrm{C}-\mathrm{H}$ bond activation steps are irreversible. The absence of $\mathrm{C}_{2} \mathrm{H}_{4-x} \mathrm{D}_{x}$ mixed isotopomers suggests that activation of ethene $\mathrm{C}-\mathrm{H}$ bonds leads only to combustion products. The normal kinetic isotopic effects measured for primary oxidative dehydrogenation reactions and for ethane and ethene combustion steps support the kinetic relevance of $\mathrm{C}-\mathrm{H}$ bond activation. Competitive reactions of ${ }^{16} \mathrm{O}_{2}-{ }^{18} \mathrm{O}_{2}-\mathrm{C}_{2} \mathrm{H}_{6}$ mixtures on supported $\mathrm{V}^{16} \mathrm{O}_{x}$ lead to the preferential initial appearance of lattice ${ }^{16} \mathrm{O}$ atoms in the product water, as expected if lattice oxygens were required for the activation of $\mathrm{C}-\mathrm{H}$ bonds, but this conclusion is not unequivocal because water formation steps are reversible and can lead to isotopic scrambling between water and lattice oxygens. The labeled oxygen content is identical for $\mathrm{H}_{2} \mathrm{O}, \mathrm{CO}$, and $\mathrm{CO}_{2}$, suggesting that the same lattice oxygen pool and active sites are involved in the kinetically relevant $\mathrm{C}-\mathrm{H}$ activation steps involved in $\mathrm{ODH}$ and combustion reactions.

Acknowledgment. This work was supported by the Director, Office of Basic Energy Sciences, Chemical Sciences Division of the U.S. Department of Energy under Contract DE-AC03$76 \mathrm{SF} 00098$.

\section{References and Notes}

(1) Kung, H. H. Adv. Catal. 1994, 40, 1.

(2) Mamedov, E. A.; Cortés Corberán, V. Appl. Catal. A 1995, 127,

(3) Albonetti, S.; Cavani, F.; Trifirò, F. Catal. Rev.-Sci. Eng. 1996 38,413 .

(4) Blasco, T.; López Nieto, J. M. Appl. Catal. A 1997, 157, 117.

(5) Hong, S. S.; Moffat, J. B. Appl. Catal. A 1994, 109, 117

(6) Zhao, Z.; Yamada, Y.; Teng, Y.; Ueda, A.; Nakagawa, K.; Kobayashi, T. J. Catal. 2000, 190, 215.

(7) Le Bars, J.; Vedrine, J. C.; Auroux, J, A.; Trautmann, S.; Baerns, M. Appl. Catal. A 1992, 88, 179.

(8) Oyama, S. T. J. Catal. 1991, 128, 210.

(9) Oyama, S. T.; Middlebrook, A. M.; Somorjai, G. A. J. Phys. Chem. 1990, 94, 5029.

(10) Thorsteinson, E. M.; Wilson, T. P.; Young, F. G.; Kasai, P. H. J. Catal. 1978, 52, 116

(11) Argyle, M. D.; Chen, K. D.; Bell, A. T.; Iglesia, E. J. Catal., in press

(12) Chen, K. D.; Khodakov, A.; Yang, J.; Bell, A. T.; Iglesia, E. J. Catal. 1999, 186, 325.

(13) Chen, K. D.; Bell, A. T.; Iglesia, E. J. Phys. Chem. B 2000, 104, 1292.

(14) Chen, K. D.; Iglesia, E.; Bell, A. T. J. Catal. 2000, 192, 197.

(15) Mars, P.; van Krevelen, D. W. Chem. Eng. Sci. (Special Suppl.) 1954, 3, 41 .

(16) Khodakov, A.; Yang, J.; Su, S.; Iglesia, E.; Bell, A. T. J. Catal. 1998, 177,343

(17) Khodakov, A.; Olthof, B.; Bell, A. T.; Iglesia, E. J. Catal. 1999, 181, 205.

(18) Iglesia, E.; Baumgartner, J. E.; Price, G. L. J. Catal. 1992, 134, 549.

(19) Price, G. L.; Iglesia, E. Ind. Eng. Chem. Res. 1989, 28, 839.

(20) Argyle, M. D.; Chen, K. D.; Iglesia, E.; Bell, A. T. Unpublished results. 